\title{
Irish Schools for Canada: Arthur Buller to the Bishop of Québec, 1838
}

\author{
Bruce Curtis
}

\section{INTRODUCTION}

The letter transcribed below is from Arthur Buller (1809-69), Lord Durham's education commissioner, to Msgr. Joseph Signäy (1778-1850), Bishop of Québec. It dates from late October 1838. ${ }^{1}$

${ }^{1}$ I am grateful to Lorraine O'Donnell for research assistance. Much of the relevant correspondence involving the bishops and the Durham mission has been published in a variety of sources, including Québec, Archdiocèse, Mandements, lettres pastorales et circulaires des Evêques de Québec, vol. troisième (Québec: Imprimerie Générale A. Coté et Cie., 1888); and Rapport de L'archiviste de la Province de Québec pour 1938-1939 (Québec: Imprimeur de Sa Majesté le Roi, 1939). The incoming correspondence is less readily available. Buller's letter on religious instruction is in Archives de l'Archdiocèse de Québec, AA, 60CN, Govt. du Canada, vol. A:225, and is dated by someone other than him "23.10.1838." Other items in the series include A:228, an outline of the draft school act, dated "29.10.1838" and A:229, a cover letter to Signäy's secretary from Buller dated in his own hand " 29 Oct 1838." The cover letter suggests that if the document I transcribe was in fact written on 23 October, it reached the bishop only on 29 October. Buller wrote,

"My dear Sir

Will you have the goodness to give the enclosed hasty exposé of my views as to the nature of the religious instruction to be adopted in schools to the Bishop of Québec $\&$ request his lordships comments on them.

I hope to be able to send him other parts of my plan before long-but in the mean [time] there can surely be no objection to expressing his opinion on the points raised in the accompanying paper.

My whole plan will certainly not be in a state to offer to criticism while I am in this country \& therefore if his Lordship [might decline? illegible] his opinion upon such parts as I am prepared with on the ground that he must see the whole-I am afraid I shall be deprived the advantage of having his opinion at all.

It is of great importance to me to get the papers back as early as possible so [pray?] lose no time in the matter.

It certainly does go strongly against my conscience-to give you all this trouble -but you do submit to it so cheerfully \& so gracefully that I am still tempted to persist.

I remain

Yrs very sincerely

Arthur Buller"

(C) Historical Studies in Education/Revue d'histoire de l'éducation 13, no. 1 (2001): 49-58. 
Buller was concerned to counter claims that proposals for non-sectarian elementary instruction for Lower Canada were aimed at the religious assimilation of Catholics. While announcing his firm opposition to clerical control over schooling, he pointed to what he hoped would be a new domain of political association, one in which allegiances would be grounded neither in sectarian religion nor in an ethnic-nationalism. Common schooling was a means to "nationalization": Buller's letter is interesting on this score alone, for the question of solidarities that might cut across ethniclinguistic lines has not disappeared from Québec politics.

Just what the substance of his new nationality would be is not specified in the letter, and Buller is silent on the matter of the language of instruction. But we can read him, in part, not only as discounting religious claims to regulate association, but also as pointing to a new space of public regulation. Religious authority would reign over morality in the schools; national officials would reign over literary instruction. We see that "nationalization" was to create "comradeship" across the lines of division in insurrectionary Lower Canada (the notion of "solidarity" was probably not yet available). We also see that a version of what Egerton Ryerson would later call our "common Christianity" was to serve as a civil religion, a non-sectarian moral infrastructure for liberal government. The draft school legislation accompanying Buller's letter made it clear that common schooling was part of a larger project for representative local democracy and rational bureaucratic state administration. The bishop was right to apprehend that Buller proposed to substitute social government for religious government in the domain of schooling. ${ }^{2}$

Buller also announced the central place of the Irish common schooling model in his plans for Lower Canada. The Irish Scripture Lessons defined the contours of "our common Christianity." Mixed lay and religious boards were an Irish innovation; and there were other Irish derivatives in the draft legislation accompanying Buller's letter.

The present historiographic neglect of the Irishness of $1830 \mathrm{~s}$ reform is striking, in my view-but then the period between the failure of the 1836 School Bill and the passage of the School Act of 1841 has yet to be studied

${ }^{2}$ On social government and the emergence of "solidarity," Jacques Donzelot, L'invention du social: Essai surle déclin des passionspolitiques (Paris: Fayard, 1984). On Ryerson and "common Christianity," Bruce Curtis, "Preconditions of the Canadian State: Educational Reform and the Construction of a Public in Upper Canada, 1837-1846," Studies in Political Economy, 10 (1983): 99-121. 
systematically. ${ }^{3}$ For the few pre-revisionist educational historians of Lower Canada, the period was a hiatus. There weren't any or many school acts, and there weren't any annual reports to read. In L.-P. Audet's account, for instance, "the troubles" were a diversion from the real business of making public schools, although he believed French-Canadians were fortunate to have had the clergy to carry the torch for better days. ${ }^{4}$

Historians after 1970 produced excellent work on the period before the insurrection, and debated hotly the nature of the educational settlement of 1841. A part from oblique mentions, however, even the systematic work of Buller's Education Commission escaped comment, and this situation has yet to be remedied, despite a recent call from J.-P. Charland for more local studies. $^{5}$

One could speculate there is an element of parochialism in the neglect of the Irish connection. Since the late 1960s, "les troubles de 37-38" have acquired a new identity as "la guerre des patriotes," an iconic and foundational event for contemporary politics in Québec. On that reading, it what happened in Lower Canada happened also in Lower Canada. Yet, from the other side of the Atlantic, the Canadas were a relatively minor part of the Empire, worth a few lines in the press but otherwise usually uninteresting. They acquired some greater importance in the mid-to-late 1830 s, not first on their own merits but because they became implicated in English political manoeuvring. Such was especially the case with respect to the Durham Mission, where members of the Radical faction, hoping to gain power in England, saw the sorting out of Lower Canada as a demonstration project for the liberal democratic reforms they were promoting at home.

${ }^{3}$ With the appropriate exceptions: Richard Chabot, Le curé de campagne et la contestation locale au Québec de 1791 aux troubles de 1837-1838 (Montréal: Hurtubise, 1975); Andrée Dufour, Tous à l'école: État, communautés rurales et scolarisation au Québec de 1826à 1859 (Ville La Salle: Hurtubise, 1996); Allan Greer, "The Pattern of Literacy in Québec, 1745-1899," Histoire sociale/Social History 11 (1978): 295-335; T. Hamel, Une siècle de formation des maîtres au Québec, 1836-1939 (LaSalle: Hurtubise, 1996); Marcel Lajeunesse, "L'évêque Bourget et l'instruction publique au Bas-Canada, 1840-1846," Revue d'bistoire de l'amérique Française 23 (1969).

${ }^{4} \mathrm{~L}$. $-\mathrm{P}$. Audet, Le système scolaire de la Province de Québec, VI: La situation scolaire à la veille de l'Union 1836-1840 (Québec: Éditions de l'Érable, 1956), 18.

'I have presented an overview of the Commission's work, Bruce Curtis, "The Buller Education Commission; or, the London Statistical Society Comes to Canada, 1838-42," in J.-P. Beaud and J.-G. Prévost, eds., The Age of Numbers/L'ère du Chiffre (Québec: PUQ, 2000), 278-97. Also, Jean-Pierre Charland, "Note Critique: L'histoire de l'éducation au Québec regard sur la production récente," Revue d'bistoire de l'amérique Française 50, 4 (1997): 599-614. 
Ireland had been sorted out educationally already, or so it seemed as Protestant opposition to national education was still gathering steam. At the very moment that Radicals were dealing with Lower Canada, they were also proposing to introduce the Irish educational system as the model for national education in England itself. ${ }^{6}$ And Ireland and Lower Canada may have looked pretty much alike to imperial eyes: alien, largely peasant populations, speaking foreign languages, Catholic and priest-ridden, and economically backward with archaic social institutions. The priests in Ireland jumped at the chance of state-supported common schooling; Buller hoped the Canadian ones would too.?

Since the "hearts and minds of the people" were a prize to be won in the political conflicts in the Lower Canada of the 1830s, we should expect that contemporaries would pay considerable attention to education. One measure of that attention is in repeated attempts to find out what was going on in common schooling and collegiate education in the countryside. By my count, there were at least six such attempts between 1835 and 1840: by the Assembly's Permanent Committee on Education; by the Gosford Commission (at least two); by the Catholic Bishops; by Durham's Education Commission; and by the Special Council.

Furthermore, with the exception of the bishops' investigation, which was aimed at forestalling Durham's Education Commission, there is an important degree of continuity in these activities, which should further discount claims that the period constituted a hiatus. The Permanent Com-

${ }^{6}$ For more detail, Bruce Curtis, True Government by Choice Men? Inspection, Education, and State Formation in Canada West (Toronto: University of Toronto Press, 1992), 53.

${ }^{7}$ Alexis de Tocqueville, who moved in Radical circles in England, recorded this exchange with an Irish priest near Tuam in co. Connaught in 1835:

"Le gouvernement anglais, dis-je, commence lui-même à apercevoir le danger. Il s'efforce en ce moment de créer des écoles qui ne soient ni catholiques, ni protestantes, et où, par conséquent, les catholiques et les protestants puissent également aller. Approuvez-vous ce plan nouveau?

-Oui, dit le curé. Mais jusqu'à présent notre paroisse s'est trouvée trop pauvre pour faire les dépenses premières qu'exige l'école établie par l'État.

-Et vous ne craignez pas, ajoutai-je, que l'instruction ainsi séparée de la religion ne soit plus funeste qu'utile?

-Non, Monsieur, dit le prêtre. Au sortir de l'école les enfants tombent dans nos mains et c'est à nous de diriger leur instruction religieuse. L'école leur apprend les éléments des connaissances humaines, l'Église leur enseigne le catéchisme. A chacun sa part. Tous les moyens d'instruire le peuple sont bons. L'instruction est un besoin vital pour l'Irlande." In A. de Tocqueville, Voyages en Angleterre, Irlande, Suisse et Algérie [Oeuvres Complètes] (Paris: Gallimard, 1958), v: 153. 
mittee proposed measures in 1836 likely urged again by its former chair, John Neilson, on the Gosford Commission. The intelligence generated by Gosford (an Irish lord) formed much of what Arthur Buller knew about Lower Canadian conditions. Signäy was appealing to Gosford after the latter's departure from the country in an effort to counter Buller. Then, Buller's Canadian version of the Irish model was modified administratively in keeping with the imperial plan to introduce representative local government into the united Canadas. Draft legislation was prepared by Christopher Dunkin, Buller's secretary, who also wrote an influential history and analysis of Lower Canadian educational policy. The Lower Canada Special Council in 1839 adopted Buller's recommendations to set the plan in motion. Christopher Dunkin briefed Poulett Thomson on educational matters after Thomson arrived as governor. The draft of the School Act of 1841, presented to the Canadian Assembly by former Special Councillor Charles Dewey Day, closely followed Dunkin's draft plan.

I hope to flesh out these claims and trace out these connections in subsequent work, but three things at least seem worth stressing: the late 1830 s in Lower Canadian education deserve our attention; the period was not a hiatus-rather, there were clear lines of continuity across it and a much schooling activity; and Lower Canadian educational development was tied to Irish development, but refracted through English politics.

\section{The Education Commission}

Lord Durham announced formation of a Commission on Education on 18 July 1838, with Arthur Buller as commissioner. The commission's mandate was to survey existing educational conditions and resources in the Lower Canadian countryside and to propose needed reforms. The Commission launched an ambitious educational survey, but Durham's resignation cut matters short and Arthur Buller left the colony in the first week of November-within days of writing to Bishop Signäy. Buller wrote his report on education while in England, but the Irish model had been selected well before the educational survey began.

Without more or less active support from the Catholic hierarchy, Buller's educational project was in difficulty. Msgr Lartigue of Montreal was intransigently opposed, and Buller pinned his hopes on the more moderate Signäy. The bishops claimed a position the hierarchy had adopted for several decades already: no system of funded schools in which a Catholic board or commission did not have directing powers over the education of Catholics was acceptable. Buller in turn was equally intransigently opposed to this position. How this antagonism worked itself out in the educational settlement of 1841 is here beyond the scope of my interest. 
THE LETTER: BULLER TO SIGNÄY, CIRCA 23-29 OCTOBER 1838

Sir, as your position in the religious world renders your opinion peculiarly valuable in that department of my Enquiries, which relates to the Religious instruction of youth, I am induced to lay before you my own views on that point and to beg the favor of your comments upon them.

I think you will agree with me that, in a country, where the distinctions of religion and race prevail to the extent that they do in Lower Canada, it is highly important that every one of its institutions should be framed with a view of uniting and nationalizing its entire population.

We know from extensive experience that the unity of nations is seriously disturbed, frequently altogether destroyed, by these distinctions, and that the surest, indeed the only way of making them harmless is to bring all classes together as much and as often as possible, and most studiously so, in their youth, when friendships are more easily formed and a mutual confidence begotten, which even the after life can with difficulty destroy.

The Children that are brought up together in the same schools and play together and are punished together become friends.

Those that are brought up at separate schools in the same neighbourhood, who are told that the reason of this separation is that the children of the rival school are heretics or belong to another nation; who have no common hopes and fears, none of those kindly associations, so easily born out of the familiarities of comradeship and so faithfully retained throughout the vicissitudes of life; such children when afterward they are brought into contact find the seeds of enmity are already sown between them; in a word the first and most decisive step towards the great end of nationalization is already taken, when the Inhabitants of a country mix freely in common schools.

But this is not achieved without some difficulty. Immediately the questions arise "Is any religious instructions to be given at these schools?, and if so, of what nature? Is it to be so limited, as to be repugnant to none? or, is it to be exclusively such as to suit the majority? ["] No doubt, much of the difficulty would be got over by a declaration that it was not the object of these schools to teach religion; that the proper teachers of that most important of all departments were the ministers of religion themselves, and that the master should neither superintend any religious exercise, nor make use of any religious book. I am aware that one of the earliest consequences of such a declaration would be, that the cry of atheism and infidelity would be raised against the whole system and would be echoed by all parties with whom it might be unpopular on other 
Grounds; and this cry unreasonable and malicious as it would be, might still make its impression and crest [ $\mathrm{sic}]$ such additional enemies to the system, as might altogether defeat its operation.

Nevertheless, if any other means of religious instruction were generally available, I should be strongly tempted to try the experiment. But such is not the case. It is rare that the minority in the rural districts of this province are provided with their ministers, and therefore, unless the [y] receive religious instruction from the Schoolmaster, they receive none at all; and the Majority again are too numerous and too much dispersed to obtain much benefit from the good of theirs. To desert the minority so circumstanced and leave them the alternative of either going without religious instructions altogether or taking what they can get at the hands of Professors of other creeds, would be impolitic, unjust and unchristian. And it would be little better than a mockery to tell the majority, that the [y] must look for theirs from a minister, who is out of reach of most of them, and too occupied to give the requisite attention to any.

Having now declared my opinion of the importance of bringing children of opposite religions together in the same schools and the necessity of providing therein some sort of religious instruction for them, I proceed to discuss the nature of that instruction - whether it shall be such as the majority in each locality pleases, or whether it shall only embrace those points which Christians of all denominations are agreed about.

The former of these plans would no doubt best satisfy the local majority; but its effect on the minority would be not only to deprive them of religious instruction. The fear of interference on the part of the master or indeed the disinclination to let their children be present when hostile opinions were being inculcated would be so great that many parents would refuse altogether to countenance such schools and thus the poor children of the minority would frequently get no education at all.

I now come to this consideration whether there is not some point and that sufficiently far on the road to which all denominations might peaceably travel together-the Historical parts of the Old Testaments-the Psalms - the Gospels and various passages throughout the sacred volume instilling the principles of Christian morality are acceptable alike to Catholics and Protestants. Such parts are eminently adapted for children. The doctrinal parts, which one religion would not trust another to interpret, are eminently unadapted for them.

Therefore, it is precisely those parts of the Scriptures, concerning which, in every way, all religions agree, that are best suited for the Instruction of children. 
Is there any difficulty in collating these parts? Or are they insufficient for the object in view? Because if not, the object is gained. The experiment has already been tried in Ireland. The very same religious difficulties, which we have to contend with here, were contended with there and the volumes of the Bible extracts which I herewith send you and which have been found sufficient to overcome those difficulties in that country, might I am persuaded, be introduced with equal success in Lower Canada.

In these volumes not a passage is to be found repugnant to the faith of any Christian. They embrace no controversial points, and the questions for explanation which the $[y]$ naturally suggest, and to which the master is limited, are most judiciously arranged at the end of each chapter. If some parts of the Bible are more important than others you will find them in these extracts. In short, all that is therein should be read, marked and digested before a child travels beyond.

Having been personally engaged in similar Enquiries in England and having taken the opinion of many well informed men here and there upon the point I am persuaded that there is a great deal more of the Scriptures in these volumes than is ever read by children at English Elementary schools and that the selection is better, (made as it has been under the superintendence of able and enlightened men) than can be expected from the discretion of the ordinary run of village schoolmasters.

Under any system that has been or ever will be, the bible has been and will be, in point of fact, read in extracts. The only difference is that in some, the extracts have been carefully made and separately bound together, and in others made at random, and read out of a book which contained a great deal else, which was not read.

Do [not] for a moment suppose that I think there is a word in the Bible which is not of the highest significance. The Child who has read and perfectly understood the extracts should, no doubt, travel beyond, but that will rarely, if ever happen at Elementary Schools, and his duties elsewhere are not the subject of enquiry at the present moment.

By these arrangements provision is made for religious instruction up to a certain point in which all can participate. However I see no difficulty in affording the different denominations the opportunity of still further and more exclusive religious instruction, which they may enjoy without offending, or interfering with each other.

The Book of Extracts I propose to be the only religious book used in schoolhours, unless catholics and protestants shall be ready to agree upon others of a similarly universal character. Out of schoolhours that is to say, either the first thing in the morning or the last thing in the evening, any minister or any body authorised in that behalf by the minister and by the 
parents of the Children shall be at liberty to teach them the Catechism or anything else that may be deemed necessary.

If confidence to such an Extract can be placed by the majority in the master, be can give them this Extra religious Instruction at either of those times, and the minority will understand that they are not to come till that is over, or to go away before it begins.

Again, the time which is not fixed upon for this purpose by the majority, may be devoted to the extra religious instruction of the minority, if they can find any one to give it.

By this arrangement the majority lose nothing, and the minority are guarante $[\mathrm{e}] \mathrm{d}$ something that the $[\mathrm{y}]$ would not otherwise get. Every child will have the means of religious instruction to a certain extract, and of a sound and unimpeachable character, and the children of the majority will continue to have precisely the same opportunity of receiving any further religious instruction which they have hither to been in the habit of enjoying, with this exception that it must be given either late or early in the day and not as heretofore perhaps in the middle of schoolhours.

I cannot anticipate any difficulty on the score of time. I presume that the extra religious instruction, insisted upon, would rarely be more than the Cathechism, and that one hour, twice a week, would be found sufficient for that purpose. If certain daily prayers should be considered indispensable, a quarter of an hour every morning or evening, or both might without difficulty be borrowed from, or added to, the usual schoolhours.

Indeed there seems something so equitable, so reasonable, so utterly inoffensive, and at the same time so very practicable in this arrangement that I fearlessly claim the assent and co-operation of every religious man and every friend of Education.

I cannot see how such assent can be refused, unless something in the book of Extracts is objected to. If it is, let it be pointed out and expurged, or if it be preferred, let another selection be made on the same principles and from the same source.

There is nothing in this system, as is apprehended, which takes, the religious instruction of the commune out of the hands of the Clergy. I $[t]$, on the contrary, conforms it to them. The Religion which it teaches in schools is such as they cannot fail to approve, and all beyond is left entirely to their direction.

The Clergy however seem scarcely content with this power. The Catholic church more particularly, lays claim to the selection of the master, and of the books to be used in schools. Under the scheme of management which I have in view, the clergyman of every denomination in every school 
district, would be an ex officio Examiner (among others) of the qualification of the person nominated by the Trustees to be master.

The Certificate of his literary attainments would be obtained elsewhere; but if any minister of religion or any of the other examiners objected to his moral habits, the charge would be brought before a superior officer of Education and [i] $\mathrm{f}$ substantiated, the nomination would be disallowed.

It should be borne in mind that it is proposed to give the greatest publicity to all this description of proceeding which circumstance coupled with [the] general activity of the superintendance will be a pretty good assurance against improper appointments. With respect of the selection of the books to be used, such as relate to religion, I have already said with the exception of the book of Extracts are left entirely to the clergy-

With respect to such as have no reference to religion, I see no foundation for their claim. If however it should be felt that sectarian insinuations had crept into any schoolbook, or that it had an immoral tendency, upon the representation of a clerical board (composed equally of catholics and protestants which I propose to hold a place in my system) these evils would be pointed out, and why not immediately remedied? There are other persons besides the clergy who would wish to discard immoral books, and the very life of my system is its diminution of sectarianism and its security against its inroads.

I am strongly disinclined to leave the sole management of education to the clergy. Not only would it open the door (which I am so anxious to close) to sectarian jealousies and sectarian injustice, but it appears to me that an institution in which the whole nation is so seriously interested should be guarded by all the precautions which the national resources can afford. That a national system of education should be directed by national officers specifically appointed for that purpose and directly responsible to the nation to an extent to which it should be inconvenient, indeed impossible, to subject the church.

You will do me a great favor by taking the earliest opportunity of giving me your opinion on these points.

I have the honor to be

Your mos hum. servant

Arthur Buller 